\title{
A Comparison of parenting stress between mothers of children with spina bifida and able bodied controls
}

\author{
Lai Choo Ong ${ }^{1 *}$, Nazli AR Norshireen², Vijayalakshmi Chandran \\ From 54th Annual Meeting of the Society for Research into Hydrocephalus and Spina Bifida \\ Vancouver, Canada. 7-10 July 2010
}

\section{Background}

To compare parenting stress between mothers of children with spina bifida and mothers of able-bodied controls, and to explore factors other than the disease that moderate stress.

\section{Materials and methods}

81 mothers of children with spina bifida and 69 mothers of children with acute, non-disabling illnesses aged 1-18 years completed the Parenting Stress Index Short Form (PSI/SF) and General Health Questionnaire-12 (GHQ). Each child's adaptive skills was assessed using the Vineland Adaptive Behaviour Scales (VABS). Medical and sociodemographic data were collected from a combination of case notes' reviews and direct interviews. Multiple regression analysis was used to determine factors related to Parental Distress (PD), Parent-Child Dysfunctional Interaction (P-CDI) and Difficult Child (DC) sub domains of the PSI.

\section{Results}

Compared to controls, mothers of children with spina bifida had lower educational levels and were more likely to be the main caregiver and not working. They also had significantly higher mean scores for the GHQ, Total PSI/SF and the PD (Parent Domain), DC (Difficult Child) and P-CDI (Parent-Child Dysfunctional Interaction) sub scales. Children with spina bifida had lower VABS scores, indicating poorer adaptive skills, than controls. Single parent status, having a child with spina bifida and higher Life Stress scores were associated with higher PD scores.

\footnotetext{
* Correspondence: onglc@ppukm.ukm.my

'Department of Pediatrics, Universiti Kebangsaan Malaysia Medical Centre,

Jalan Yaacob Latif, 56000 Kuala Lumpur, Malaysia Full list of author information is available at the end of the article
}

Single parent status, higher Life stress and GHQ scores were associated with higher DC scores. The only factor associated with higher P-CDI scores was lower VABS scores.

\section{Conclusions}

Factors such as life stress events, single parent status, maternal mental health status and the child's adaptive skills appear to moderate the impact of spina bifida on various aspects of parenting stress.

\section{Author details}

'Department of Pediatrics, Universiti Kebangsaan Malaysia Medical Centre, Jalan Yaacob Latif, 56000 Kuala Lumpur, Malaysia. ${ }^{2}$ Department of Pediatrics, Institute of Pediatrics, Jalan Raja Muda, 50300 Kuala Lumpur, Malaysia.

Published: 15 December 2010

doi:10.1186/1743-8454-7-S1-S28

Cite this article as: Ong et al:: A Comparison of parenting stress between mothers of children with spina bifida and able bodied controls. Cerebrospinal Fluid Research 2010 7(Suppl 1):S28.

Submit your next manuscript to BioMed Central and take full advantage of:

- Convenient online submission

- Thorough peer review

- No space constraints or color figure charges

- Immediate publication on acceptance

- Inclusion in PubMed, CAS, Scopus and Google Scholar

- Research which is freely available for redistribution

Submit your manuscript at www.biomedcentral.com/submit
( Biomed Central
C Biomed Central 